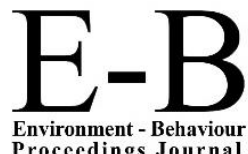
Proceedings Journal
AIVCE-BS-2, 2020ShahAlam

https://www.amerabra.org; https://fspu.uitm.edu.my/cebs; https://www.emasemasresources.com/ AMEABRA International Virtual Conference on Environment-Bahaviour Studies, $2^{\text {nd }}$ Series cE-Bs, FSPU, Universiti Teknologi MARA, Shah Alam, 02-03 Dec 2020

\title{
Empirical Study on Motivation: Embedding design thinking mini project
}

\section{Sharifah Zannierah Syed Marzuki, Che Asniza Osman, Siti Zahrah Buyong, Laila Mohammad Kamaruddin}

\author{
Malaysian Academy of SME \& Entrepreneurship Development (MASMED), \\ Faculty of Business and Management, Universiti Teknologi MARA, Shah Alam, Malaysia \\ szannierah@uitm.edu.my, asnizaosman@yahoo.com, siti280@uitm.edu.my, laila489@uitm.edu.my \\ Tel : 603-55435659
}

\begin{abstract}
Design thinking is a critical component and has a potential impact on business competitiveness. The effort should start early so that younger generations can develop their intellectual abilities to be able to think creatively and develop innovative products or services through the ideation stage until commercialization. The significance of this study is building interest among students taking a subject on entrepreneurship on the importance of new product development and the stages that they need to go through before commercialization takes place. The research aims to determine whether educator-student interaction, student to student interactions, and critical thinking skills can influence motivation.
\end{abstract}

Keywords: Design Thinking; Motivation; Creativity; Innovation

eISSN: 2398-4287@ 2020. The Authors. Published for AMER ABRA CE-Bs by e-International Publishing House, Ltd., UK. This is an open access article under the CC BYNC-ND license (http://creativecommons.org/licenses/by-nc-nd/4.0). Peer-review under responsibility of AMER (Association of Malaysian Environment-Behaviour Researchers), ABRA (Association of Behavioural Researchers on Asians) and cE-Bs (Centre for Environment-Behaviour Studies), Faculty of Architecture, Planning \& Surveying, Universiti Teknologi MARA, Malaysia.

DOI: https://doi.org/10.21834/ebpj.v5i15.2458

\subsection{Introduction}

An act has more than one motivation, and any motivated behavior, either preparatory or consummatory, must be well understood, leading to an expression or satisfaction (Maslow, 1942). Furthermore, some action is highly motivated, weakly motivated, and not motivated at all. Motivation theory plays a pivotal role in student success (Rugutt \& Chemosit, 2009). Previous research has shown that motivation influences students' academic achievement (Wattanasupachoke, 2012; Dunne \& Martin, 2006; Gambrell, 2001). The increasing demand for understanding the relationships between motivation and educator-student relationship is impressive in designing effective teaching and learning. The design thinking approach may have implications for the readiness of students before entering the job market.

Looking back on behaviorism during the mid-1970s that made a comeback where theorists acknowledged that human behavior was dynamic and could be stimulated by the interaction with the environment (Basset-Jones \& Lyold, 2005). This positive reinforcement is extended through social stimuli to which an individual will respond. It is highlighted by Basset-Jones and Lyold (2005, p. 940) that 'a key priority within the domain of the knowledge management literature has centered on the conversion of tacit knowledge embedded in the employee into explicit knowledge embedded in the systems and processes of the organization.' The inclusion of the Design Thinking

eISSN: 2398-42870 2020. The Authors. Published for AMER ABRA cE-Bs by e-International Publishing House, Ltd., UK. This is an open access article under the CC BYNC-ND license (http://creativecommons.org/licenses/by-nc-nd/4.0). Peer-review under responsibility of AMER (Association of Malaysian Environment-Behaviour Researchers), ABRA (Association of Behavioural Researchers on Asians) and cE-Bs (Centre for Environment-Behaviour Studies), Faculty of Architecture, Planning \& Surveying, Universiti Teknologi MARA, Malaysia.

DOI: https://doi.org/10.21834/ebpj.v5i15.2458 
Mini Project (DTMP) in teaching and learning induces growth and achieves the entrepreneurial traits and thus creating acculturation and develop an entrepreneurial environment on its own.

This study investigates the character and extent of the relationship between educator and the student interactions, students' critical thinking skills, student-to-student relations, and student motivation. The main focus is to find ways to increase students' motivation, particularly in learning entrepreneurship subjects, to investigate whether a design thinking mini project can enhance critical thinking skills, educator-student interaction, and student-to-student relations. Previous research found out that motivation appeared to be an independent variable concerning cognitive skills that include necessary thinking skills (Kanfer \& Ackerman, 1989; Rugutt \& Chemosit, 2009). However, in this study, motivation is used as a dependent variable to test design thinking during the learning process. The literature on the basis and design thinking is exceptionally sparse.

As discussed above, this study highlights the introduction of DTMP. This DTMP is an innovative mini class project to ensure the students know the significance of developing a new product development. This DTMP is allocated among the Science and Technology students taking an entrepreneurship subject called Technology Entrepreneurship (ENT 600), emphasizing developing a technology product and commercializing it. The practical part of DTMP in and outside the classroom is seen to be directly or indirectly lead to positive academic change and create an entrepreneurial mindset. DTMP emphasizes being creative and innovative while meeting real people in developing make-believe kind of technology products or services.

The purpose of this study is to determine whether educator-student interaction, student to student relations, and critical thinking skills can enhance the ability to influence motivation. This study is based on the research questions as below:

1. Does the regression equation from the set of three predictor variables allow to predict motivation?

2. Do critical thinking skills predict well student motivation, control for student-to-student relations, and educator-student interaction?

3. How far does a design thinking approach motivates the students?

\subsection{Design Thinking and Motivation Theory}

Strategists have been increasingly accepting the notion of a design thinking concept and agreed that it is essential to create innovation (Clark \& Smith, 2008; Wylant, 2008). Additionally, design thinking helps instill creativity and aesthetics values in every operational process, not only developing the looks of products. Specific methods need to be undergone before the final product is ready to make its way and taking further steps in offering sustainable competitive advantages (Wattanasupachoke, 2012). Design thinking techniques also encourage customers to be involved in providing valuable inputs for product outcomes. Adding more values to the designs is a source of innovativeness. It is supported by creating breakthrough innovations or by improving the existing products or services. In realizing this, the basic needs of learning and acquire knowledge are of importance. It appears to be a part of curiosity solution to the general problems (Gambrell, 2001; Maslow, 1942).

Motivating people is crucial for them to make changes and to contribute ideas. Herzberg's two-factor theory has emphasized motivating people to contribute ideas and supported by previous literature on motivation theories that human relations integrated with the economic situations and socio-psychological perspective (Basset-Jones \& Lloyd, 2005). Agreed by Kröper, Fay, Lindberg, and Meinel (2010) that motivation is a central psychological aspect to endure the project outcomes's creativity. Blending in motivation and innovation is prior before a design thinking learning process takes place. Again, it is being reiterated on sustaining competitive advantage and social impact in previous studies with respect to the design thinking process (Dorst, 2011; Brown \& Wyatt, 2010; Beckman \& Barry, 2007; Dym, Agogino, Eris, Frey \& Leifer, 2005).

Understanding the relationship between motivation and educator-student should be investigated further with motivation theory regarding classroom environment and academic performance (Rugutt \& Chemosit, 2009). Instilling design thinking during the learning process is vital for improving strategies and creating knowledge through motivation. Within this context, Dym et al. (2005) suggested that more educators should be trained in design pedagogy and capable of teaching future enhancement design.

\subsection{Design Thinking Mini Project (DTMP)}

Design Thinking is a critical component and has a potential impact on business competitiveness. The effort should start early so that younger generations can develop their intellectual abilities to recognize connections, redefine problems, plan and analyze possible ideas, solutions, and be near potential customers to sustain. According to Plattner, Meinel, and Weinberg (2009), the design thinking process model has six phases that include :

1. Understand

2. Observe

3. Point of view

4. Ideate

5. Prototype and

6. Test.

They added that deciding when to proceed to the next phase and how to get through the whole process depends on the design team. Here, the design team for this DTMP initiated to build interest among students taking Technology Entrepreneurship (ENT 600) on the importance of new product development. In technological evolution, students are encouraged to think innovatively about a problem or have the ability to evaluate a business opportunity.

In this DTMP, students are required to meet potential customers and gain inputs. Once all information is gathered, students will discuss their product design further with their team members, develop their product design, and build a prototype with limited resources. 
The idea of offering limited resources is to educate students that networking is prominent in the real business environment. They need to find suitable market players to work together, and they should be mindful of competition. Finally, they need to present their output in five minutes of business pitching. A previous study on DTMP has been conducted, and it is found that students learned the stages in the new development process that covered the ideation until commercialization. It is evidenced in the findings that motivation could induce the students to think innovatively and create an opportunity-oriented personality. This design thinking mini project is the motivation that directly influences the students' innovativeness (Syed Marzuki, Osman, Buyong \& Mohammad Kamaruddin, 2018).

As mentioned earlier, technology keeps changing, and market players must be aware of maintaining the status quo with other competitors and changing customers' tastes and preferences. With this mini-project, students are close to their potential buyers by conducting a simple market survey and gaining input from them to prepare their next step in developing their innovative product, thus expected to penetrate the market in a real business situation. It is imperative to enhance the development of an environment that encourages and supports students to be creative and innovative, thus expressing their ideas and participate in discussions in other motivation characteristics (Rugutt \& Chemosit, 2009; Astin, 1993). This is in line with a study on interrelations between motivation, creativity, and emotions in design thinking processes by Kröper et al. (2010), who found that motivation is a critical predecessor to achieve design and innovation. They stressed an interesting note, 'our study suggests that motivation itself is affected by pursuing tasks that require learning, exploration and creative problem solving' (p.102).

\subsection{Methodology}

This study's population was the students of Science and Technology clusters in Universiti Teknologi MARA (UiTM) who took Technology Entrepreneurship subject (ENT 600). The students came from various faculties that include Faculty of Applied Sciences, Faculty of Health Sciences, Faculty of Sports Science \& Recreation, and Faculty of Architecture, Planning \& Surveying. Regarding the survey instrument, online questionnaires using Google forms were employed as the main technique for primary data collection. Analysis of previous researches and critical reviews on the topics have contributed useful insights into the questionnaire development. A pilot test was conducted before to the fieldwork to gain feedback and improve the instrument.

The students represented a broad array of individuals from different programs and backgrounds that served interesting findings. Students responded to a set of questions using five Likert scales that range from $1=$ strongly disagree to $5=$ strongly agree that asked them on educators and student interaction (Part A), student to student relations (Part B), critical thinking skills (Part C), motivation (Part D) and demographic (Part E).

\subsection{Findings}

The results gathered for this study are as listed; a) descriptive statistical analyses of demographic b) internal consistency (Cronbach Alpha) c) regressions. A total of 254 responses were recorded. This sample was 29 percent male and 71 percent female (Table 1). Most of the respondents came from the Faculty of Applied Science $(n=134,52.8 \%)$ and the least from the Faculty of Health Science $(n=13,5.1 \%)$ as shown in Table 2.

Table 1. Gender

\begin{tabular}{lll}
\hline & Frequency & Percent \\
\hline Male & 73 & 29 \\
Female & 181 & 71 \\
\hline Total & $\mathbf{2 5 4}$ & $\mathbf{1 0 0}$ \\
\hline
\end{tabular}

Table 2. Faculties

\begin{tabular}{lll}
\hline & Frequency & Percent \\
\hline Faculty of Architecture, Planning and Surveying & 61 & 24.0 \\
Faculty of Health Science & 13 & 5.1 \\
Faculty of Sport Science and Recreation & 46 & 18.1 \\
Faculty of Applied Science & 134 & 52.8 \\
\hline Total & $\mathbf{2 5 4}$ & $\mathbf{1 0 0 . 0}$ \\
\hline
\end{tabular}

The instrument's subscales, items per scale, and Cronbach alpha reliabilities are presented in Table 3.

Table 3. Cronbach Alpha

Reliability Coefficients

\begin{tabular}{lll}
\multicolumn{3}{c}{ Reliability Coefficients } \\
\hline Variable & Variable Description & Alpha Reliabilities \\
\hline ESI (5) & Educator and Student Interaction & .92 \\
SSR (5) & Student to Student Relations & .85 \\
CTS (5) & Critical Thinking Skills & .90 \\
MOT (4) & Motivation & .89 \\
\hline \multicolumn{2}{c}{${ }^{*}$ Number of items comprising measure }
\end{tabular}


Cronbach's alpha reliability coefficients of educator and student interaction are 0.92 ; student to student interaction is 0.85 , critical thinking skills is 0.90 , and motivation is 0.89 . as these are higher than 0.70 , it could be concluded that the instruments are reliable (Nunnally, 1978; Hair et al., 2006).

Table 4. Correlations

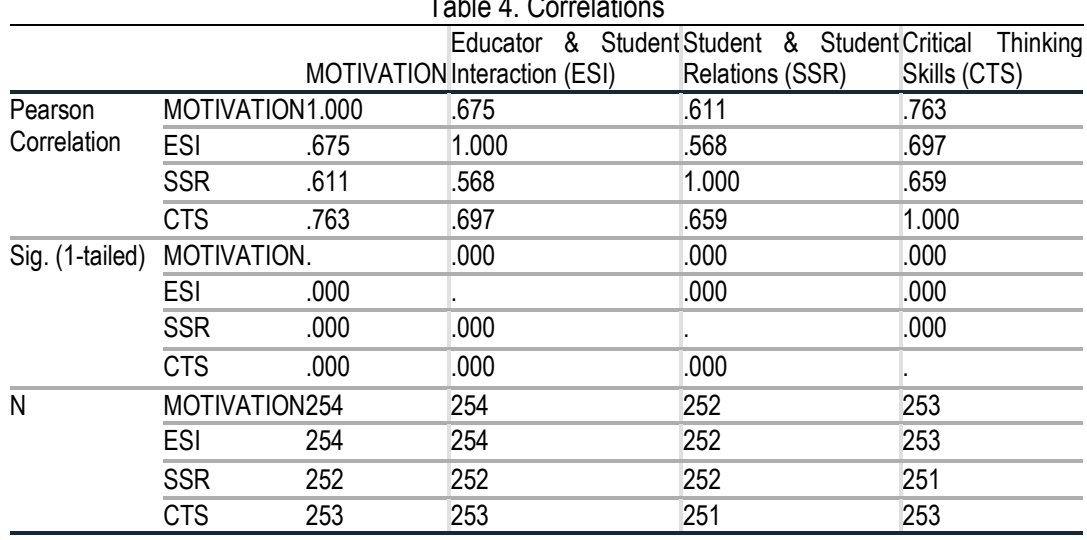

The three predictor variables (LSI, SSR \& CTS) have negative correlations with the outcome. It is shown in Table 4 that all three scales (ranged 0.611 to .763) are greater than 3.0, and they correlate strongly. Correlations between CTS, ES, I and SSR are also well correlated.

Table 5. Coefficients ${ }^{\mathrm{a}}$

\begin{tabular}{|c|c|c|c|c|c|c|c|c|c|c|c|c|}
\hline \multirow{3}{*}{$\frac{\text { Model }}{1(\text { Constan }}$} & \multicolumn{2}{|c|}{$\begin{array}{c}\text { Unstandardize } \\
\text { Coefficients } \\
\text { Std. }\end{array}$} & d Standardized & \multirow[b]{2}{*}{$t$} & \multicolumn{3}{|c|}{$\begin{array}{l}95.0 \% \\
\text { Confidence } \\
\text { Interval for B } \\
\text { Lower Uppe }\end{array}$} & \multicolumn{2}{|c|}{$\begin{array}{l}\text { Correlations } \\
\text { Zero- }\end{array}$} & \multicolumn{3}{|c|}{$\begin{array}{l}\text { Collinearity } \\
\text { Statistics }\end{array}$} \\
\hline & B & Error & Beta & & Sig. & Bounc & dBoun & dorder & rPartial & Part & t Tolerance & eVIF \\
\hline & t) 3.443 & 3.751 & & 4.58 & 34.000 & 01.964 & 4.922 & & & & & \\
\hline ESI & 179 & .040 & .249 & 4.52 & 28.000 & 0.101 & .257 & .675 & .277 & .175 & 5.493 & 2.027 \\
\hline SSR & 1117 & .042 & .145 & 2.76 & 33.006 & 6.034 & .200 & .611 & .173 & .107 & 7.543 & 1.842 \\
\hline CTS & .362 & .044 & .494 & 8.22 & 24.000 & 0.275 & .449 & .763 & .464 & .317 & 7.412 & 2.427 \\
\hline
\end{tabular}

The independent variables were measured for possible multicollinearity problems through tolerance statistics available under the regression feature. Tolerance value for predictable variables in this study ranged from .412 to .543 and well above .10, and all VIF value is below than 10 (ranged from 1.842 to 2.427 ) that shows no multicollinearity. It is indicated in Table 5 that all predictor variables should be maintained. The results showed that all three variables (ESI, SSR and CTS) significantly contributed to the regression model.

\subsection{Discussion}

This study showed that educator to student interaction, student to student relations, and critical thinking skills were statistically significant predictors of motivation. Previous studies have highlighted that further research needs to focus on this vital area of integrating motivation with individual and institutional factors (Wattanasupachoke, 2012; Dorst, 2011; Sukirno \& Siengthai, 2011; Rugutt \& Chemosit, 2009). Educators played substantial roles in adapting and adopting design thinking mini-projects to provide an ideal learning environment for the students/learners.

This positive and innovative teaching can enhance the development of a new way of learning. Students are taught to be proactive and creative, encouraging them to discuss and contribute their ideas, help, learn, and motivate peers. The design thinking mini project is a good pedagogical method to increase educator and student interaction and increase the relationship between students while building and practicing critical thinking skills together with motivation. The analysis has shown that DTMP is seen as an important process in creating innovation for the effective development of individual and institutional characteristics.

It is gathered from the empirical data analysis that the results turn out that all predictive variables do have a direct relationship and significant with motivation. Critical thinking skills are crucial in creating innovative product/service value. This is supported by Wattanasupachoke (2012, p. 10) that stressed design thinking and values, although his study focussed on businesses and companies.

This study focuses on design thinking, which is increasingly crucial for business nowadays. It will lead to the development of ideas and innovations that can make better changes within organizations. It will also help create more product/service value, increase the ability to respond to customer needs, and bring competitive advantages in differentiation to the companies. 


\subsection{Conclusion}

Design thinking is now seen as a new paradigm in dealing with problems (Dorst, 2011). Thus, it combines originality and aesthetics in the operatinal process in particular and builds the products' look (Syed Marzuki et al., 2018; Wattanasupachoke, 2012). The Design Thinking Mini Project (DTMP) application on students who took Technology Entrepreneurship (ENT 600) subject has gained valuable knowledge of innovation. This study found that all predictive variables seem essential and significant for students or learners to be motivated to become creative and innovative. Strengthening the contributing factors of the relationship between educators and students, students to students, critical thinking skills, and motivation have ultimate implications for improving strategies in ensuring students to be critical thinkers. Involvement in lateral thinking must start early in education to impart innovative thinking in organizations, thus creating a competitive advantage in the future. Those young minds are to be exposed and encouraged out-of-the-box thinking and breakthrough ideas. The study has pointed out that the three variables have integrated both individual and institutional factors that boost the students' motivation to apply critical thinking skills to inspire and developing ideas and producing innovative prototypes. Here, stimulation is considered the first step in the design thinking process that follows with the ideation and building up prototypes. In essence, design thinking techniques also include a depth understanding of customer needs, where customer surveys, focus groups, observation, and feedback are necessary to be amalgamated with creative ideas. In DTMP, students are required to conduct an experiment with 'potential buyers' and undergo all the stages. This is to create a situation on commercial possibility and to reduce market risks. It can be concluded that the regression results did allow us to reliably predict motivation where educators and peers do contribute to increasing the motivation in learning DTMP.

As discussed earlier critical thinking skills has also a significant impact on the motivation of the students as they need to discuss and brainstorm to inspire, to come up with the idea/s, and to generate prototypes. Embedding a design thinking approach can motivate students by expanding their efforts to innovate by following the stages in the design thinking techniques guided by well-trained educators and supporting peers thus, innovativeness leads to better motivation. Creative invention and innovation are being developed through ideation and working prototypes by creative and innovative learners/students.

\section{Acknowledgements}

The authors are grateful to the Institute of Research Management \& Innovation, Universiti Teknologi MARA (UiTM) for the awarded research grant with the project code: 600-IRMI 5/3/LESTARI (034/2018). Special thanks also go to all respondents who have taken part in the survey and the lecturers who have helped remind them to participate and make the study run smoothly. DTMP is indeed an extensive and comprehensive learning tool in making students feel motivated and enjoyed the learning process. Finally, the authors are particularly thankful to the Malaysian Academy of SME \& Entrepreneurship Development (MASMED) and the Faculty of Business and Management, UiTM, for the support given in the completion of this research.

\section{Paper Contribution to Related Field of Study}

This DTMP contributes to enhancing innovation study among the students in entrepreneurship education and other subjects that they are taking. With this, the analysis showed that there is a significant impact on the motivation level among them.

\section{References}

Astin, A. W. (1993). What matters in college? Four critical years revisited. San Francisco Jossey-Bass.

Basset-Jones, N., \& Lloyd, G. C. (2005). Does Hertzberg's motivation theory have staying power? Journal of Management Development, 24(10), 929-943

Beckman, S. L., \& Barry, M. (2007). Innovation as a learning process: Embedding design thinking. California Management Review, 50(1), 25-56.

Brown, T., \& Wyatt, J. (2010). Design thinking for social innovation. Stanford Social Innovation Review, 31-35.

Clark, K., \& Smith, R. (2008). Unleashing the power of design thinking. Design Management Review, 19(3), 8-16.

Dorst, K. (2011). The core of 'design thinking' and its application. Design Studies, 32(6), 521-532.

Dunne, D., \& Martin, R. (2006). Design thinking and how it will change management education: An interview and discussion, 5(4), 512-523.

Dym, C. L., Agogino, A. M., Eris, O., Frey, D. D., \& Leifer, L. J. (2005). Engineering Design Thinking, Teaching and Learning. Journal of Engineering Education, $103-120$.

Gambrell, L. B. (2001). What we know about motivation to read. In R. F. Flippo (Eds.), Reading researchers in search of common ground (pp. 129-143). Newark, DE: International Reading Association.

Kanfer, R., \& Ackerman, P. L. (1989). Motivation and cognitive abilities: An integrative/aptitude-treatment interaction approach to skill acquisition. Journal of Applied Psychology, 74(4), 657-687.

Kröper, M., Fay, D Lindberg, T., \& Meinel, C. (2010). Interrelations between motivation, creativity and emotions in design thinking process - An emprical study based on regulatory focus theory. Presented at 11th International Conference on Design Creativity (ICDC, November, 2010), Kobe, Japan. 
Maslow, A. H. (1942). A theory of human motivation. Cambridge University.

Plattner, H., Meinel, C., \& Weinberg, U. (2009). Design thinking. Munich: mi-Verlag.

Ruggut, J., \& Chemosit, C. C. (2009). What motivates students to learn? Contribution of student-to-student relations, student-faculty interaction and critical thinking skills. Education Research Quarterly, 32 (3), 16-28.

Syed Marzuki, S. Z., Osman, C. A., Buyong, S. Z., Mohammad Kamaruddin, L. (2018). Design Thinking Mini Project: Think Innovatively In Novel Ways.International Conference On Teaching And Learning (ICOTAL 2018), 20-21 February 2018, UiTM Cawangan Melaka, Kampus Bandaraya (KBM).

Wattanasupachoke, T. (2012). Design thinking, innovativeness and performance: An empirical examination. International Journal of Management and Innovation, 4(1), 1-14.Wylant, B. (2008). Design thinking and the experience of innovation. Massachusetts Institute of Technology Design Issues, 24(2), 3-14.. 